\title{
The Value of Revisiting and Extending Previous Studies - the case of Islam in the UK press
}

\author{
Paul Baker and Tony McEnery, Lancaster University
}

\section{Introduction}

Discourse analyses often tend to be time bound. A discourse is observed, its nature characterized and an analysis concludes. This, of itself, is not problematic - analyses have beginnings and ends. Researchers invest the time and effort into a research question as their research programme demands and then move on to their next question. A slightly more problematic situation arises, however, when discourse is described and then assumed to remain static. Such an analysis will background the fact that discourse is dynamic. While we may concede that dynamism in discourse may be topic sensitive and that such change may vary in terms of speed and degree, it is nonetheless probably the rule rather than the exception that discourse is Protean over time. However, it can be easy to refer to past analyses and assume that they still have contemporary relevance. For example, L'Hôte (2010) studies the language of globalization in the British Labour party in the period 1994 to 2005 using a 234,387 word corpus of documents produced by the party. Yet the study has been cited since as being about 'the particular meaning of "globalisation" in Labour manifestos' (Evans and Schuller, 2015). Similarly Kambites (2014:339) says that L'Hôte's paper 'analyses the use of the term 'globalization' by successive UK governments and finds that "new Labour discourse is significantly more concerned with the process of globalisation than Conservative discourse"'. Both papers imply that the findings of L'Hôte are not time bound but at the very least that possibility should be accepted, otherwise contemporary discourse may be mischaracterized. Nonetheless, the difficulty of extending some studies, especially where they are large in scale, may be so daunting that a full investigation of the on-going dynamism of a discourse may not be undertaken. ${ }^{1}$

In this chapter we will return to one major study, Baker, Gabrielatos and McEnery (2013) to explore how, in the period following their study, the discourse that they studied changed, if at all. Baker et al explored the representation of Muslims and their religion, Islam, in the British national press. They did this by examining 143 million words of British newspaper articles from 1998-2009. While their study is an exhaustive account of the period covered, numerous subsequent global events relating to, or involving, Muslims, such as the Arab Spring and the rise of ISIS, mean that the possibility clearly exists that discourse around Islam has changed somewhat since 2009. Additionally, the political context in the UK has changed; there was a change in government in 2010, with a Conservative-led coalition replacing Gordon Brown's Labour Party. The popularity of the English Defence League as well as increasing support for UKIP suggest that Britain's social barometer has become more right-leaning after 2009. With both the political context and the world context of reporting about Muslims and Islam in the UK press having changed, the opportunity presents itself to consider an important methodological issue - how stable might the analysis of a discourse prove to be in the time following the completion of a study?

To explore how stable the discourse around Muslims and Islam was in the UK press, we extended the original study, analyzing a corpus of articles about Islam and Muslims from

\footnotetext{
${ }^{1}$ An example of such an extension is the work of Blinder and Allen (2105) who looked at the representation of refugees and asylum seekers in a 43 million word corpus of UK press material from 2010-2012 in a complementary study to the investigation of the same subject by Baker et al (2008) using a 140 million word corpus of newspaper articles covering 1996-2005.
} 
2010-2014, which for convenience we will call Corpus B, making comparisons back to the findings from the original 1998-2010 study which was based on a corpus we will call Corpus A.

\section{Collecting the articles}

In order to be able to make a fair comparison, we collected Corpus B using the same method of collecting newspaper articles that we used for Corpus A. This involved gathering articles from the online news database Nexis UK. We collected articles between January 2010 and December 2014, using the same search term used to collect Corpus A. As before we collected national newspapers and their Sunday editions.

However, even in the process of data collection we encountered our first example of how the discourse around these topics may have changed - since the collection of Corpus A, there had been changes to the availability of some newspapers. The Business was a weekly newspaper which went out of print in February 2008, so we were not able to collect that newspaper. Additionally, The News of the World stopped publishing in 2011 but was replaced with The Sunday Sun, so we have collected that newspaper as the Sunday equivalent of The Sun. These changes, in themselves, open the possibility of an overall change in discourse.

Table 1 shows the number of words for both the older and the new corpus, for each newspaper.

\begin{tabular}{|l|l|l|l|l|}
\hline \multirow{2}{*}{ Newspaper } & \multicolumn{2}{|c|}{ Corpus A: 1998-2009 } & \multicolumn{2}{c|}{ Corpus B: 2010-2014 } \\
\hline & Total words & $\begin{array}{l}\text { Percentage of } \\
\text { the corpus }\end{array}$ & Total words & $\begin{array}{l}\text { Percentage of the } \\
\text { corpus }\end{array}$ \\
\hline Business & 577234 & 0.3938 & N/A & N/A \\
\hline Express & 6419173 & 4.379286 & 3510462 & 4.394532 \\
\hline Guardian & 24344632 & 16.60839 & 19740632 & 24.71208 \\
\hline Independent & 25591916 & 17.45931 & 7622731 & 9.542428 \\
\hline Mail & 17216224 & 11.74525 & 5379219 & 6.733914 \\
\hline Mirror & 8067444 & 5.503768 & 3117405 & 3.902488 \\
\hline Observer & 10264984 & 7.002973 & 3516404 & 4.40197 \\
\hline People & 663192 & 0.452443 & 336226 & 0.420901 \\
\hline Star & 2669466 & 1.821162 & 1343924 & 1.682376 \\
\hline Sun & 5018404 & 3.423654 & 4131110 & 5.171483 \\
\hline Telegraph & 16125825 & 11.00135 & 12623169 & 15.80217 \\
\hline Times & 29621874 & 20.20862 & 18561226 & 23.23566 \\
\hline Total & 146580368 & 100 & 79882508 & 100 \\
\hline & & & & \\
\hline
\end{tabular}

Table 1. The structure of the two newspaper corpora. 
It should be borne in mind that the broadsheets make up the majority of the data in both corpora because they have longer articles and more articles per issue than the tabloids. For the 2010-2014 corpus, just two broadsheet newspapers, The Guardian and The Times make up almost half of all the data. Adding in the other broadsheets (The Independent, The Observer and The Telegraph), amounts to three-quarters of the data. As a proportion of the corpus, The Guardian (a liberal newspaper) actually contributed more in Corpus B than Corpus A (8\% more), so it should be borne in mind that the overall composition of corpus data is different between the two time periods examined, and this may subsequently impact on results found

\section{Number of articles per month}

Looking at the volume of data produced and the trend over time, two features of the Baker et al study are shown to be stable - the volume of data increases at points in time where violent events involving Muslims occurs and, over time, the overall trend is for more articles to be written mentioning Muslims and Islam. Figure 1 below shows both of these points. The figure combines results from Corpus A and Corpus B to show long term trends in the data.

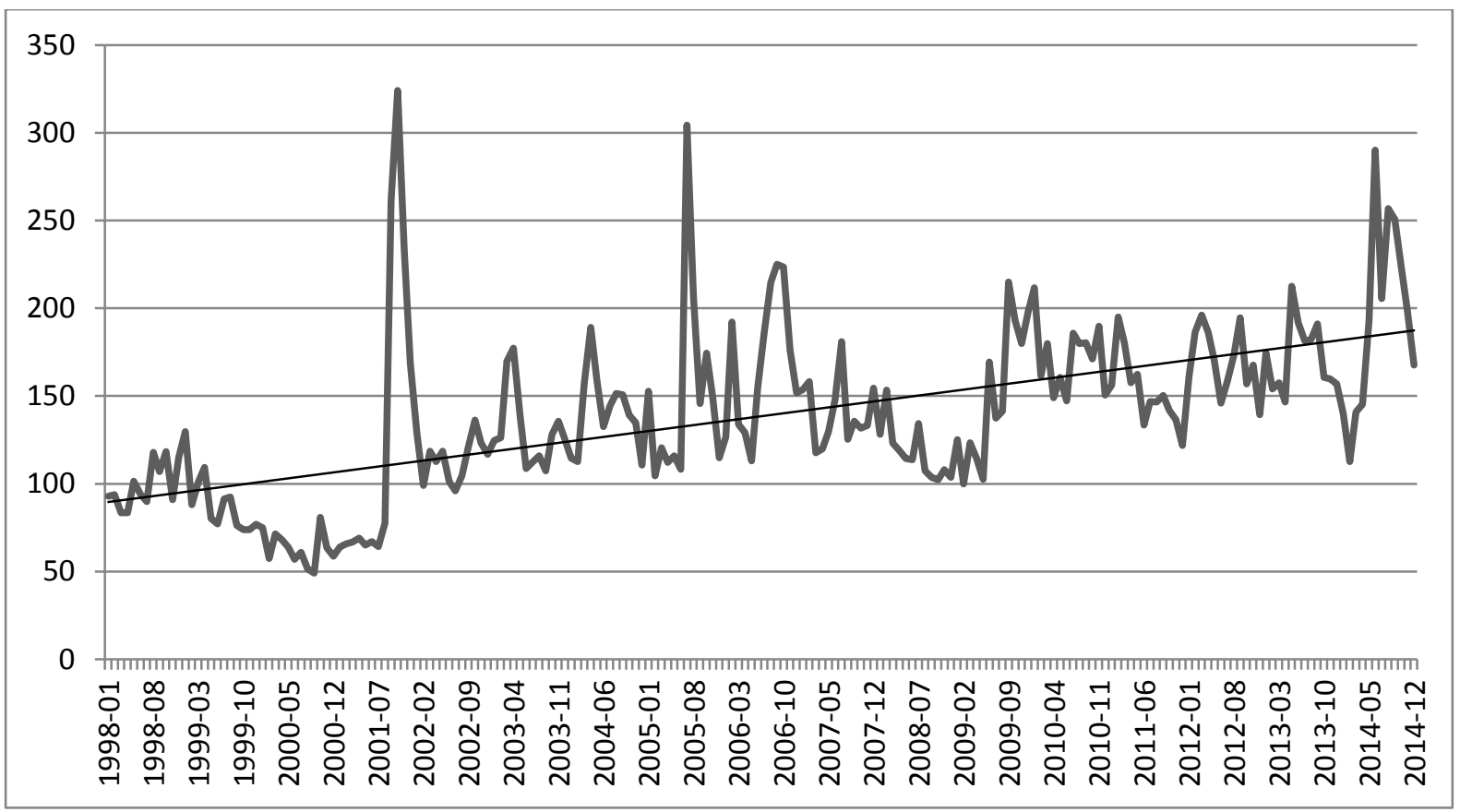

Figure 1. Average number of articles about Islam per newspaper per month, 1998-2014.

This graph shows a trend line indicating that press interest in Islam and Muslims has continued to increase, particularly since the events of 9/11. The rise of the Islamic State and its invasion of Iraq in 2014 appear to have caused a third large spike in reporting (with 9/11 and $7 / 7$ being two other spikes). But since the end of 2009, there appears to have been a notable upturn in reporting, following a general fall from 2005-2009.

Yet the overall volumes of data over time, while indicative of a potential change, does not describe or account for it. To look at this issue, we decided to explore the differences between Corpus A and Corpus B using the keywords procedure. We wanted to focus on keywords which indicated a difference between the two periods and then to reflect on how those keywords either meshed with, or indicated a change in, our previous findings. So we contrasted the language of the 1998-2009 articles with those from 2010-2014 to identify words which occurred significantly more frequently in one of these periods when compared 
against the other. These keywords were then used as a way of exploring the continuation or change of findings in our original study of Corpus A.

\section{Stability - what has remained the same}

Stability in the analysis across the two periods was the exception. Yet there were some broadly stable results. Firstly, the relative frequency of the word islamic, shown by Baker et al (2013:44) to be associated with extremism, retains this association. Secondly, the strong association of Muslims and Islam with conflict in the UK press (Baker et al, 2013:62-63) has also been sustained. Thirdly, The 'horror discourse' around the veil identified in 1998-2009 is still present in 2010-2014, with the veil described as a shroud and veiling women referred to in negative terms, e.g. as Daleks or Darth Vader. Finally, the original study reported that the phrase devout muslim was negatively loaded; this is still true in the 2010-2015 articles where we found references to devout Muslims described them as cheating (e.g. failing drug tests, having affairs etc.), becoming radicalised, engaging in extremist activity or clashing with 'western' values in some way. ${ }^{2}$ However, even in these cases, there are some slight changes. For example, reporting of the Islamic State group's activities has served to intensify the association of the word islamic with extremism. Similarly, in the 1998-2009 corpus the word forms relating to conflict (see Baker et al 2012:59) constituted 2.72\% of the corpus. For the 2010-2014 data these words constituted $2.75 \%$ of that corpus. So while overall these findings have remained the same, minor details relating to the findings have been subject to flux. However, these changes are minimal by comparison to the major changes that have taken place across the two time periods, hence the bulk of this paper will be devoted to a discussion of these differences.

\section{What has Changed}

The dynamic nature of discourse is shown clearly when we consider other findings arising from Baker et al (2013). In the following sub-sections we will consider a range of findings from the first study and show how, in the second study, these features have changed. Throughout, the figures quoted in the tables are normalised frequencies per million words as this allows for an ease of comparison between the two corpora.

In the analysis that follows, after an initial focus on which countries are mentioned and the prevalence of conflict lexis in the corpora, we will focus on 6 key questions, relating to major findings by Baker et al, in order to illustrate the dynamism of the discourse across the two periods with regard to how, in Corpus B relative to Corpus A:

- the words Muslim, Muslims and Islam are used;

- Muslim women and men are represented;

- different branches of Islam are constructed;

- strength of belief is communicated and used;

- extremism is constructed;

- radicalization is discussed.

These investigations are guided by words which are key when the two corpora are contrasted.

\subsection{Country and conflict keywords}

\footnotetext{
${ }^{2}$ For example "A JUDGE yesterday ruled that a devout Muslim woman must remove her full face veil if she gives evidence in court" (The Sun, January 23, 2014).
} 
In terms of location, there has been a shift away from stories about conflicts or attacks in Iraq, Palestine, and America, which are key when Corpus A is compared to Corpus B. When Corpus B is compared to corpus A, we find instead that in Corpus B Syria, Libya, Iran and Egypt are key.

In terms of conflict, as noted the strong relationship with both Muslims and Islam is relatively stable across the two corpora. However. when the lexis used to realise the presentation of conflict in the two corpora is examined, a clear difference emerges. The top keywords (in descending order) in Corpus A, when compared to Corpus B, are war, terrorist, terrorists, attacks, bomb, bombs, terrorism, suicide, invasion, destruction, raids, and hijackers. Key in Corpus B, when compared to Corpus A are islamist, rebels, crisis, revolution, protesters, protest, sanction, rebel, activists, uprising, islamists, jihadists, jihadist and jihadi. How can we interpret these findings? World events tend to be a major driving force in the contexts that Muslims and Islam are written about - such events align well with news values. We therefore hypothesise that since 2009 references to terrorism have fallen sharply in articles about Islam particularly because large-scale orchestrated attacks like 9.11 and 7.7 in Anglophone countries in particular have been less marked. Many words which directly refer to conflict have also seen sharp falls: war, bomb, raids, destruction, attacks. Yet other words relating to conflict of a principally civil kind have increased, such as crisis, revolution, protests, sanctions and uprising. While stories about armed conflict have not gone away, reference to political/civil conflict has risen dramatically. This makes us reflect again upon the apparently stable finding linking Muslims and Islam with conflict. While the picture in terms of the frequency of conflict words appears relatively stable, the relative proportions of the different types of conflict words are not stable. Concerns over Iran's nuclear intentions, and reporting of events around the Arab spring have replaced the focus on the Iraq war and 9.11. While mentions of Al Qa'eda and the Taliban have been reduced, they have been replaced by other groups like Islamic State, Boko Haram and the Muslim Brotherhood. There are also more references in 2010-2014 to rebels, activists, Islamists, protestors and jihadists. So rather than being framed around fear of terrorist attacks, the discourse between 2010-2014 is more linked to revolution, political protest and Islam as a political force. The concept of jihad and those engaged in it (while less frequent than some of the other terms) has also risen over time. These changes in turn impact on the frequency of the selection of different items of conflict lexis.

\subsection{Muslim, Muslims and Islam}

In our original study we were particularly interested in words which appear next to muslim, muslims and islam (as well as islamic, which has been discussed above) as, if they are frequent enough, they are likely to trigger the concept even before it is mentioned. For example, if a person encounters the phrase "Muslim fanatic" enough times, we hypothesize that they are likely to be primed to think of the word fanatic if they hear the word Muslim by itself. So, as in the initial study, we looked for patterns like Muslim [X], as well as [X] Muslims and [X] Islam.

\section{Muslim}

The top ten words immediately following Muslim in Corpus A are, in descending order of frequency, community, world, council, women, leaders, countries, cleric, country, men and communities. In Corpus B they are brotherhood, community, women, world, men, woman, communities, convert, countries and council. 
The change, tokened by the contrast between the two lists, is quite marked. We see a strong rise in the phrase Muslim Brotherhood, indicating the salience of stories coming out of the Arab Spring and the uprising in Egypt. In 2010-2014 Brotherhood follows over 1 in every 10 mentions of Muslim. The Muslim council appears to be of less interest to journalists in the later period, as do Muslim leaders and the phrase Muslim cleric. So apart from the Muslim Brotherhood, it appears that there is now less focus on people or groups who are seen as leading various Muslim communities.

The term Muslim convert has become more common though, although this term usually refers to stories about Muslim converts who are involved in crime, usually terrorism or militancy e.g:.

In the feverish atmosphere of Kenya's war on terror, rumours abound as to the whereabouts of Samantha Lewthwaite, the Muslim convert from Aylesbury who is on the run after a foiled bomb plot. (Telegraph, July 16, 2012)

Yet there is an element of stability in the word - Muslim world, Muslim countries and Muslim community continue to be phrases used frequently to refer to Muslims. By continuing to use terms like Muslim world, Muslim community and Muslim countries the British press continue to collectivise large numbers of Muslims as living in similar circumstances, implying that they are separate from everyone else.

What of the plural form, Muslims? For Corpus A the top ten right hand modifiers are British, young, Shia, moderate, Sunni, Bosnian, fellow, other, radical and devout. For Corpus B they are British, young, Sunni, Shia, moderate, Bosnian, fellow, other, radical and devout.

This example is of interest as, although the two wordlists appear very similar, rank orderings within the lists have changed, indicating a shift in focus in the discourse. Similarly, the normalised frequencies for some words have changed, even though their ranking has not. For example, the ordering of mention of Sunni and Shia Muslims has been reversed. Also, although references to British Muslims have decreased over time (from 8.1 examples per million words in Corpus A to 4.9 in Corpus B) this is still the most common way that Muslims are referred to. Further changes in the representation of Muslims emerge when we consider what British Muslims are reported as doing in Corpus B. They are described as alienated, sometimes impressionable and prone to radicalisation:

The alienation of many young British Muslims goes deep - some despise society enough to want to harm it. (The Times, February 2011)

Maybe after the 7/7 bombings and numerous failed plots to blow up aeroplanes, nightclubs, an airport and a shopping centre it's not so surprising. Nobody knows the true level of radicalisation among British Muslims. (The Guardian, July, 2010)

They are described as having travelled (often to places like Syria to join ISIS):

According to our intelligence agencies, some 500 young British Muslims have travelled to Syria to join the Islamic State or other terrorist organisations. (The Mail, August, 2014)

They are expected to condemn jihad and terrorism (but a minority are sometimes described as not doing so): 
While most British Muslims wholeheartedly condemn the killers, we know from bleak experience that a significant minority will tell opinion pollsters they actually endorse what was done (The Mail, May 2013)

While the link through collocation of Muslims to alienation and radicalization is reported in Corpus A by Baker et al (2013: 42) travelled is not. This is strongly indicative of a shift in the discourse to focus on the issue of Muslims travelling to join jihadi groups and the wish for British Muslims to discourage such travel by condemning it. In the case of condemn in particular, the press has shifted its stance from a neutral one in Corpus A, where it discussed the reaction or response of Muslims to terrorist acts, to a situation where it was seeking to shape that response, i.e. encouraging them to condemn such acts.

A focus on the word young reveals further differences. This collocate is not reported in the analysis of Muslims in Corpus A by Baker et al (2013, 42-44) yet in Corpus B it is notable that young and British both often appear together at the same time as modifiers of Muslims. As a result, many of the collocates of young Muslims are the same as those of British Muslims. Those for young Muslims actually show a stronger concern about radicalisation. Young Muslims are described as impressionable, disaffected, rootless, angry and susceptible. They are at risk of being lured, recruited, indoctrinated or brainwashed to commit crimes or jihad.

The Prison Service has long been concerned at the spread of radical Islam inside Britain"s jails. Experts say a tiny number of fanatics, most serving long sentences, have huge influence over disaffected young Muslims. (The Sun, May 2013)

Cameron said a clear distinction must be made between the religion of Islam and the political ideology of Islamist extremism, but the "non-violent extremists" who disparage democracy, oppose universal human rights and promote separatism were also "part of the problem", because they lure young Muslims onto the path of radicalisation, which can lead them to espouse violence. (The Times, February 2011)

So while Muslims are discussed as a collective group the most salient pattern is in the context of the radicalisation of young British Muslims.

The last word we will consider in this section relates to the belief system that Muslims follow, Islam. In this case looking at the collocates immediately preceding the word is revealing. In Corpus A, the top ten such collocates are radical, militant, political, Shia, insulting, fundamentalist, anti, British, insult and moderate. For Corpus B it is radical, anti, militant, political, Shia, Sunni, moderate, fundamentalist, insulting and British. Note that these lists of collocates are similar, but not the same. One collocate is unique to each list insult for Corpus A and militant for Corpus B. Also, these lists are ordered from strongest to weakest collocates - hence it is clear to see that the rank ordering of the collocates has changed too.

These minor changes, however, mask some real similarities. As with Islamic, the word Islam continues to be associated with extremism, with the words radical, militant and fundamentalist appearing in the top 10 left hand collocates (although moderate also appears). Other words suggest conflict: insulting, insult (which have both decreased over time) and anti (which has increased over time):

Dorje Gurung, a Nepalese teacher in Qatar, who was imprisoned for 12 days in May 2013, after a 12-year-old student accused him of insulting Islam, believes the men are 
likely to be held without any form of information or support. (The Guardian, September 2014).

Note, however, that this extremism has been reinforced in Corpus B by the new top ten collocate militant, which reinforces this discourse of extremism in the corpus focussed upon the word Islam. By the same token, however, the loss of insult from the top ten collocate list for Corpus B perhaps tokens a weakening of the link of the word to insult Islam. Nonetheless, the collocate insulting is still present in the Corpus B top ten collocate list, meaning that the link between Islam and the process of insulting persists, though the reality of insults to Islam sometimes appear questionable according to the narrative voice of some articles.

Saudi liberal activist Raif Badawi was sentenced to 1,000 lashes, 10 years in prison and a heavy fine for insulting Islam. In fact, his crime was to establish an online discussion forum where people were free to speak about religion and criticise religious scholars. (The Independent, May 2014)

Overall, Islam is still often constructed in Corpus B as an entity that is prone to feeling insulted, with any insults provoking strong reactions from its adherents.

\subsection{Representation of Gender}

The terms Muslim women and Muslim men are frequent in the corpus. We found that in the previous study, Muslim women tended to be discussed in terms of the veil, due to a debate which took place in 2006 after comments made about veiling by the then Home Secretary Jack Straw. Muslim men were most often discussed in terms of their potential for radicalisation. How have Muslim men and women been written about since 2010?

Table 2 shows collocates (words which frequently occur near or next to the word or phrase we are interested in) of Muslim women in the two time periods - we only considered content words (nouns, verbs or adjectives) which occurred 10 times or more. Words that are unique to 2010-14 are shown in bold.

\begin{tabular}{|c|c|c|}
\hline Category & Collocates 1998-2009 & Collocates 2010-2014 \\
\hline The veil and dress & $\begin{array}{l}\text { wear, veils, veil, wearing, remove, } \\
\text { worn, hijab, full, Straw, cover, Jack, } \\
\text { niqab, faces, face, headscarves, } \\
\text { veiled, Straw's, dress, covering, head, } \\
\text { headscarf, traditional, burkas, burka, } \\
\text { wore, dressed, covered, veiling, } \\
\text { burqa, burkha }\end{array}$ & $\begin{array}{l}\text { wear, wearing, veil, face, veils, } \\
\text { burka, full, faces, worn, dress, } \\
\text { cover, hijab, veiled, covering, } \\
\text { niqab, public, remove, } \\
\text { headscarves, burkas, modesty, } \\
\text { coverings }\end{array}$ \\
\hline $\begin{array}{l}\text { Identity words } \\
\text { (age, gender and } \\
\text { relationships) }\end{array}$ & $\begin{array}{l}\text { young, men, children, women, people, } \\
\text { girls, old, generation, husbands, } \\
\text { marry }\end{array}$ & $\begin{array}{l}\text { young, children, women, men, } \\
\text { people, group, marry, girls, } \\
\text { woman, }\end{array}$ \\
\hline $\begin{array}{l}\text { Reporting and } \\
\text { feeling }\end{array}$ & $\begin{array}{l}\text { said, saying, feel, asked, call, told, } \\
\text { asking, comments, say, ask, talk, } \\
\text { revealed, believe, suggested, called, } \\
\text { calling, urged, prefer, hope, know, } \\
\text { wants, claimed, speak, question, } \\
\text { warned, understand }\end{array}$ & $\begin{array}{l}\text { said, says, see, feel, talking, } \\
\text { think, say }\end{array}$ \\
\hline Locations & British, Britain, country, world, & British, Britain, France, \\
\hline
\end{tabular}




\begin{tabular}{|l|l|l|}
\hline & $\begin{array}{l}\text { London, English, western, Bosnian, } \\
\text { constituency, society, Blackburn, } \\
\text { France, Europe, street, Serb, town, } \\
\text { French, Arab, community }\end{array}$ & $\begin{array}{l}\text { French, English, London, } \\
\text { world, country, central, } \\
\text { western, Arab }\end{array}$ \\
\hline Freedom & $\begin{array}{l}\text { rights, allowed, forced, ban, issue, } \\
\text { choose, debate, power, support, help, } \\
\text { free, allow, row, required, banned, } \\
\text { encourage, campaign, choice, } \\
\text { freedom }\end{array}$ & $\begin{array}{l}\text { law, banned, } \text { oppressed, } \\
\text { choose, allowing, debate, free }\end{array}$ \\
\hline Religion & Others & $\begin{array}{l}\text { Islamic, faith, religious } \\
\text { role, take, way, rape, protect, } \\
\text { minority, majority, come, } \\
\text { made, designed, swimming, } \\
\text { sport, living }\end{array}$ \\
\hline
\end{tabular}

Table 2. Collocates of Muslim women.

We first examined some of the new collocates of Muslim women. For example, modesty is used to refer to wearing the burka or hijab. Modesty is generally represented as a positive aspect of being a Muslim woman, although some authors cite this point in order to problematise it:

For many, the hijab represents modesty and freedom of choice, but we cannot ignore that it is also one of the most contentious and divisive issues of modern times - within the Muslim community as well as outside it (Guardian, February 16, 2010)

Other authors imply that adherence to modesty does not necessarily mean that a Muslim woman cannot be stylish:

She is part of an expanding group of bloggers in London and America, known as hijabistas, who are proving that it is possible to wear a hijab, a symbol of modesty, and be stylish at the same time. (Sunday Times, January 19, 2014)

Swimming referred mostly to stories about swimming pools that ran special sessions for Muslim women only. Such sessions were viewed as problematic and contribute towards a wider discourse that was frequently encountered in the 1998-2010 corpus of Muslims receiving "special treatment described as unnecessary":

The Walsall debacle comes six months after The Daily Express revealed how Hull City Council was accused of running Muslim women-only swimming sessions in secret - to the fury of regular baths users. (The Express, July 6, 2010)

The collocate rape most often refers to atrocities that took place in Bosnia in the 1990s:

In 1996 a UN tribunal indicted eight Bosnian Serb soldiers and policemen for the rape of Muslim women. (Daily Mirror, June 12, 2014)

Sport is seen as an area which Muslim women should be encourage to get involved in more:

RIMLA AKHTAR, winner of the Community Award, believes more needs to be done to engage Muslim women in sport at the grassroots level, writes Andrew Longmore. (Sunday Times, December 8, 2013) 
Of the 18 times that oppressed collocates with Muslim women, almost all of them cite the idea that Muslim women are oppressed in order to disagree with the notion:

"The media portray Muslim women as oppressed and subjugated and Islam is often presented as misogynist and patriarchal," she said, and her book was intended as an antidote to that. (The Observer, March 16, 2014)

"People use this idea that Muslim women are oppressed as an excuse for pulling off their head coverings. (The Sunday Times, July 20, 2014)

The collocate designed most often refers to an all-in-one swimsuit for Muslim women, called a burkini, with the following case giving a somewhat unflattering description:

TV chef Nigella Lawson has admitted she resembled "a hippo" when she wore a burkini on Bondi Beach. The 51-year-old caused a storm two years ago by donning the all-in-one swimsuit designed for Muslim women during a visit to Australia. (The Sun, February 25, 2013)

Finally, role collocates with Muslim women 12 times of which 8 are used positively in the phrase role model.

"I want to give something back to the community and be a positive role model for young Muslim women - and for young women in general." (Daily Star, March 25, 2011)

So since 2010 there has been a small but significant increase in positive discourses around Muslim women, particularly in terms of questioning their oppression or discussion of positive female role models. However, the main picture is a continuation of older discourses which focus on Muslim women as victims, receiving special treatment, victimisation or problematizing their dress.

In terms of stability in the discourse, he table above suggests that the main focus around Muslim women - veiling - has not actually changed, with a similar set of words relating to veiling and dress collocating mostly with Muslim women. Other categories in the table tend to be linked to veiling, particularly the one relating to freedom. So has the debate around veiling changed at all since 2010? In the 1998-2009 study we concluded that the veil was discussed negatively and seen as an "issue", characterised by ambivalence and conflict. Some Muslim women were described as oppressed by the veil, others as demanding to wear it. There were a wide range of arguments given as to why Muslim women should not veil, and they were discussed in metaphors relating to things that glide on water, soft furnishings and (most negatively) frightening supernatural monsters.

To examine the 2010-2014 articles, we retrieved cases of the following pattern:

insist*/demand*/force*/right/cho* to wear/wearing [the veil or any related clothing item]

We only counted cases where the construction uncritically or unquestioningly referred to the veil as a choice, right, demand or imposition.

The table below shows what patterns we found for each newspaper.

\begin{tabular}{|l|l|l|l|l|}
\hline & $\begin{array}{l}\text { Forced } \\
\text { to wear }\end{array}$ & $\begin{array}{l}\text { Right to } \\
\text { wear it }\end{array}$ & $\begin{array}{l}\text { Choosing } \\
\text { to wear it }\end{array}$ & $\begin{array}{l}\text { Demanding } \\
\text { to wear it }\end{array}$ \\
\hline
\end{tabular}




\begin{tabular}{|l|l|l|l|l|}
\hline & it & & & \\
\hline Times & 10 & 3 & 4 & 5 \\
\hline Telegraph & 11 & 1 & 9 & 6 \\
\hline Sun & 3 & 0 & 2 & 3 \\
\hline Mail & 4 & 2 & 3 & 4 \\
\hline Express & 4 & 0 & 2 & 2 \\
\hline Star & 0 & 0 & 0 & 3 \\
\hline Mirror & 5 & 0 & 2 & 1 \\
\hline Guardian/Observer & 10 & 2 & 14 & 6 \\
\hline Independent & 1 & 2 & 2 & 1 \\
\hline Total & 48 & 10 & 38 & 31 \\
\hline
\end{tabular}

Table 3. Patterns around Veiling for Muslim women.

We can see that the most frequent construction here is of Muslim women being forced to wear the veil. The two negative constructions (force and demand/insist) are more frequent together than the more positive ones (right or choice). Uncritical descriptions of the veil as a right were relatively infrequent.

We note the higher frequency of the veil being described as a choice by The Guardian, although this newspaper also has fairly high representations of it being linked to compulsion also.

The following table compares proportions of these constructions of wearing the veil to the earlier set of data.

\begin{tabular}{|l|l|l|l|l|}
\hline & $\begin{array}{l}\text { Forced to wear } \\
\text { it }\end{array}$ & Right to wear it & $\begin{array}{l}\text { Choosing to } \\
\text { wear it }\end{array}$ & $\begin{array}{l}\text { Demanding to } \\
\text { wear it }\end{array}$ \\
\hline $1998-2009$ & $28.5 \%$ & $34.8 \%$ & $25.5 \%$ & $10.6 \%$ \\
\hline $2010-2014$ & $37.7 \%$ & $7.8 \%$ & $29.9 \%$ & $24.4 \%$ \\
\hline
\end{tabular}

Table 4. Patterns around Veiling - change over time (summary).

Over time, the veil is more likely to be described in negative terms, either as Muslim women being forced into wearing it, or in terms of them demanding or insisting on wearing it.

Discussion of the veil as a right appears to have sharply declined, although it is slightly more likely to be described as a choice.

We also looked at arguments given for why Muslim women should not veil. This was found by carrying out a search on terms describing the veil, appearing in the same vicinity as the word because. Of the 135 cases of these, 32 gave arguments as to why a Muslim women should not wear the veil. These are shown in the table below. 


\begin{tabular}{|l|l|}
\hline It makes communication with the wearer difficult & 13 \\
\hline It's a symbol of oppression of women & 5 \\
\hline It's alien to the culture it's been worn in & 3 \\
\hline It reduces your field of vision & 3 \\
\hline It compromises national security & 3 \\
\hline It's a symbol of extremist Islam which is seen as intolerant & 2 \\
\hline It over-excites men & 2 \\
\hline It's false consciousness & 1 \\
\hline It's offensive & 1 \\
\hline
\end{tabular}

Table 5. Arguments against veiling.

The argument about the veil (particularly face-covering veils) making communication with the veil-wearer difficult was the most frequently cited. In particular a court-case where a veiled female juror was asked to step down was mentioned, as well as there being references to school-teachers who veil their faces.

I'm with Ken Clarke when he says that women should not be allowed to wear the fullface veil in court because it is difficult to give evidence from inside a kind of bag'. (Daily Mail, November 5, 2013, Richard Littlejohn)

People are nervous about speaking to burka wearers. That's because we want direct communication, not just through eye contact but through interesting and sometimes revealing facial expressions. We want to see the lips move. (The Sun, April 10, 2010)

Again, the picture is of stability at one level, change on another. There is still a focus on the veil in the second corpus. However, the main argument against Muslim women wearing the veil has changed from the oppression of women (1998-2009) to a focus on difficulties surrounding communication with the veil wearer (2010-2014). The increase in arguments relating to difficulties in communication could perhaps be seen as 'strategic' by those who oppose the veil, as it does not require its opponents to make claims about Islam's ideology or attitude towards women. Instead, the argument focusses on a more 'practical' concern, which may be difficult to counter as being Islamophobic. This could suggest that opponents of Islam are developing more careful and subtle arguments to support their views.

Having explored the changing representation of Muslim women in the UK press, let us now consider Muslim men. The following table shows collocates (occurring 10 times or more) of Muslim men for the two time periods. Again, those in bold are unique to the last period.

\begin{tabular}{|l|l|l|}
\hline Category & Collocates 1998-2009 & Collocates 2010-2014 \\
\hline $\begin{array}{l}\text { Identity words (age, } \\
\text { gender and relationships) }\end{array}$ & $\begin{array}{l}\text { young, boys, women, } \\
\text { children, wives, whore, } \\
\text { dating }\end{array}$ & $\begin{array}{l}\text { boys, young, women, girls, } \\
\text { marry, children, }\end{array}$ \\
\hline Locations & $\begin{array}{l}\text { Srebrenica, Bosnian, British, } \\
\text { Britain, Serb, Serbs, Iraq, } \\
\text { London, Asian, town }\end{array}$ & $\begin{array}{l}\text { Srebrenica, Bosnian, British, } \\
\text { Pakistani, Serb, Britain, } \\
\text { Asian, }\end{array}$ \\
\hline
\end{tabular}




\begin{tabular}{|c|c|c|}
\hline Killing & $\begin{array}{l}\text { massacre, killed, massacred, } \\
\text { slaughter, murder, murdered, } \\
\text { slaughtered, died, war, } \\
\text { killing, suicide, bombers }\end{array}$ & $\begin{array}{l}\text { massacre, killed, murdered, } \\
\text { killing, slaughter, massacred, } \\
\text { deaths, unarmed, murder }\end{array}$ \\
\hline Reporting and feeling & $\begin{array}{l}\text { said, say, believed, feel, says, } \\
\text { told }\end{array}$ & \\
\hline Law and order & $\begin{array}{l}\text { arrested, accused, executed, } \\
\text { innocent, alleged, trial, law }\end{array}$ & $\begin{array}{l}\text { accused, arrested, charged, } \\
\text { guilty, convicted, found }\end{array}$ \\
\hline Radicalisation/terrorism & $\begin{array}{l}\text { impressionable, disaffected, } \\
\text { radicalised, radicalisation, } \\
\text { training, terror, radical, Abu }\end{array}$ & radicalised \\
\hline Abuse & & $\begin{array}{l}\text { grooming, gangs, abuse, } \\
\text { force }\end{array}$ \\
\hline Other & $\begin{array}{l}\text { white, allowed, disgraceful, } \\
\text { angry, born, beards, forces, } \\
\text { gathered, way, dignity, see, } \\
\text { get }\end{array}$ & white, forces \\
\hline
\end{tabular}

Table 6. Collocates of Muslim men.

Apart from the reporting words, many of the categories used to discuss Muslim men are the same in both periods, with discussion of them as victims of violence and also as guilty of crimes. There is a new category though: abuse. The words grooming, abuse and gangs collocate with Muslim men in stories about the sexual abuse of (often) white girls.

And when Jack Straw condemned the grooming by British Muslim men of Pakistani origin of vulnerable white girls, he was instantly flamed as a bigot. (The Times, January 22, 2011)

This was far from a one-off case. Police operations going back to 1996 have revealed a disturbingly similar pattern of collective abuse involving small groups of Muslim men committing a particular type of sexual crime. (Daily Mail, January 10, 2011)

The authorities have been just as reprehensible in their reluctance to tackle the sickening exploitation of white girls by predatory gangs of Muslim men. (The Express, May 17, 2012)

Force does not occur in stories about sexual abuse but relates to cases where Muslim men apparently force women to wear the veil.

We also note that the category of radicalisation/terrorism has fewer words in it in 2010-2014. However, overall, the concept of radicalisation has grown during this period (as shown earlier). What seems to be the case is that it is not as gendered a concept as it previously was. When the British press speak about radicalisation, they talk about young British Muslims, but do not mention gender as much as they did in the past. So radicalisation has become a more gender-neutral subject than it used to be. 
In this category only one word: radicalised occurs as a collocate with Muslim men more than 10 times. However, this occurs in similar ways to its use in 1998-2009, with fears about Muslim men being radicalised (particularly young Muslim men).

The father of the Muthana brothers, Ahmed Muthana, suggested yesterday that young Muslim men were being radicalised at "pop-up" meetings in Cardiff rather than at any mosque or via internet videos. (The Guardian, June 24, 2014)

THOUSANDS of lone wolf extremists could launch similar attacks to the Woolwich bloodbath, a senior police officer warned yesterday. And Assistant Met Commissioner Cressida Dick said the threat cannot be eradicated while young Muslim men are radicalised via the internet. (Daily Mirror, December 20, 2014)

In Corpus B, stories about Muslim men in the British press have focussed around them as either victims or perpetrators of crime, with particular focus on the sexual abuse of white girls or the risk of them being radicalised.

\subsection{Branches of Islam}

The earlier study found that about half the newspapers refer to Islam generally rather than discussing different branches of Islam like Sunni, Shia and Wahhabi. Is there any evidence that this behaviour has changed? Figure 2 shows the proportions of times that a newspaper refers to these Sunni and Shia Islam in both Corpus A and Corpus B. The figure below shows the proportions for each newspaper for the two time periods.

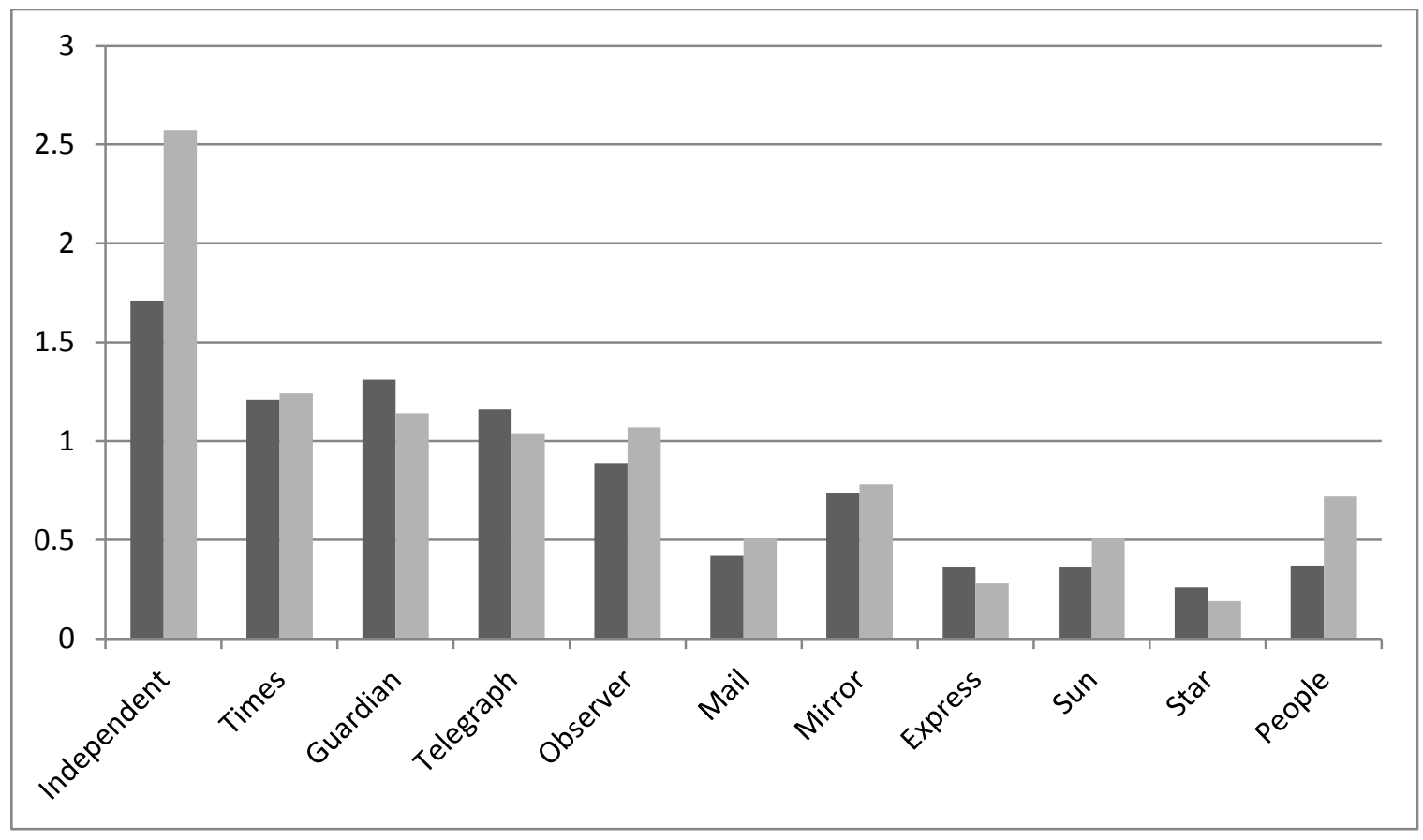

Figure 2. Proportion of mentions of different branches of Islam for each newspaper.

The first bar shows 1998-2009, while the second shows 2010-2014. It can be seen that The Independent has greatly increased the proportion of times it refers to branches of Islam as opposed to writing more generally about Islam. Six other newspapers have also gone in this direction (although not hugely). However, The Guardian, Telegraph, Express and Star have gone the other way and refer to the branches less than they used to. 
Generally a distinction can be made between the broadsheets and the tabloids here, with all the broadsheets referring more often to branches of Islam rather than Islam in general, while the reverse is true of the tabloids.

So again we have some stability. British tabloids continue to paint a simplistic picture of Islam, not usually referring to or distinguishing between different branches like Sunni and Shia, although The Mirror is the tabloid that makes the most effort to do this. On the other hand, all the broadsheets are more likely to refer to branches of Islam as opposed to Islam itself, with The Independent being most likely to do this. Yet within this overall picture of stability, variation by newspaper can be notable, especially with regard to The Independent and The People. The change underlying this apparent stability becomes all the more obvious if we consider change over time not by period covered by the corpus, but by year. Figure 3 below shows how overall references to different branches of Islam have changed since 1998.

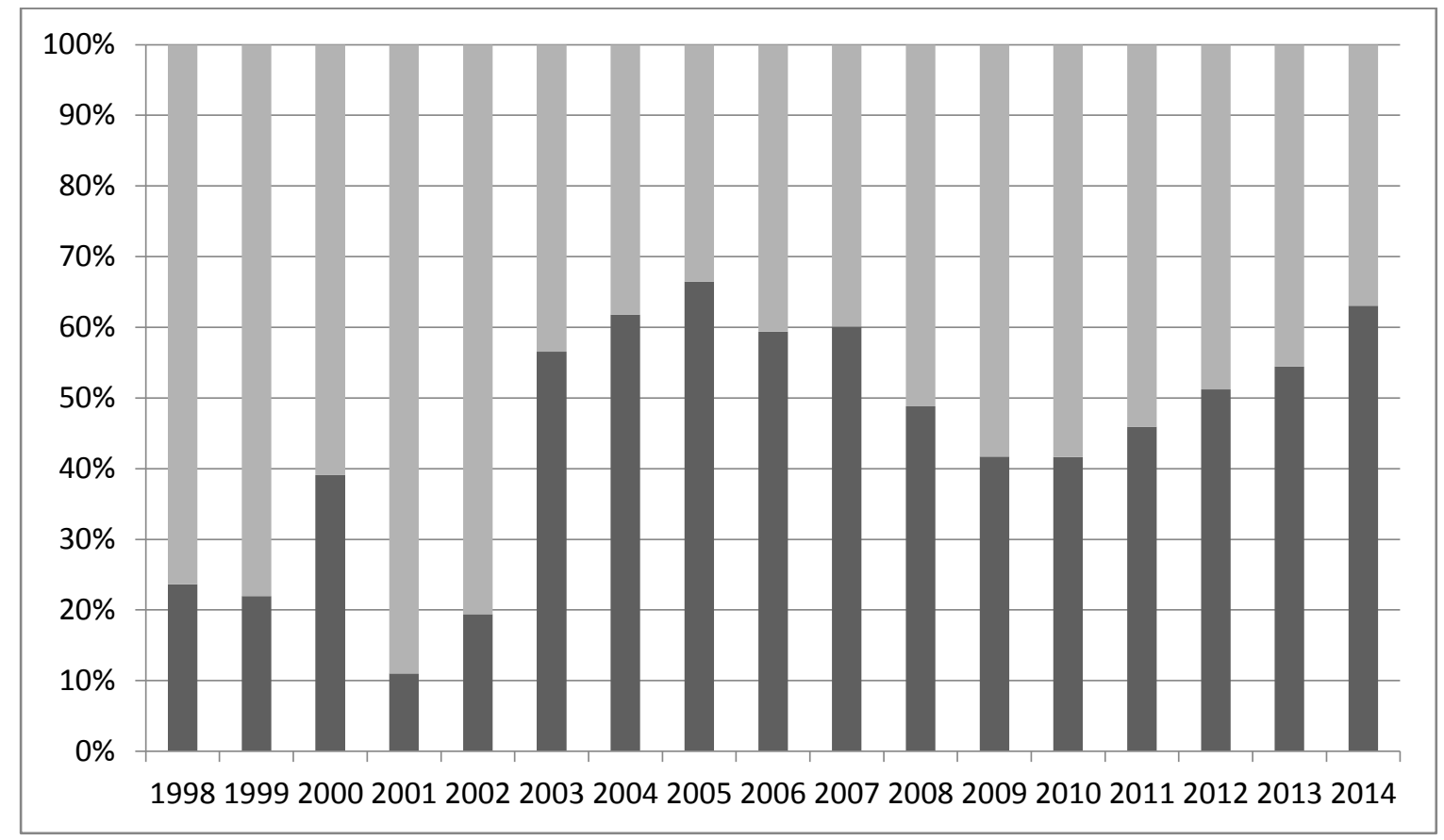

Figure 3. References to Sunni, Shia, Sufi, Salafi and Wahhabi over time. Dark grey denotes the proportion of mentions of references to branches of Islam (e.g. Sunni, Shia, Wahhabi), light grey bars denote references to Islam.

Since the start of the new collection of data (2010), newspapers have begun once again to increasingly make distinctions between different branches of Islam, as opposed to simply referring to Islam itself. However, such references often relating to fighting between Sunnis and Shias (often in Iraq) and the Sunni uprising in Syria.

\subsection{Strength of Belief}

This section examines how Muslims and Islam are associated with different levels of belief. Phrases like Muslim extremist and Muslim fanatic were found to be extremely common in our earlier study, and one way of gauging whether representations of Muslims have changed is to examine whether such terms have increased or decreased. We would argue that the presence of such terms, particularly in large numbers, is of concern as readers of newspapers would begin to unconsciously associate Muslims and Islam with extremism. Such terms tend to be more frequent in the broadsheets, like The Guardian and The Times, simply because these 
newspapers contain more print than the tabloids. So simply counting the number of times a phrase occurs in a newspaper, and then comparing across newspapers, isn't the best way of ascertaining the scope of the problem. Instead, we have taken an approach which looks at the proportion or percentage of cases a word like extremist occurs next to Muslim in each newspaper. This takes into account the fact that some newspapers may mention Muslims a lot and some not very much at all.

Our initial study looked at labels which could be used to refer to people. So we were interested in terms like Muslim extremist or fanatical Muslim. We classified three different types of belief as shown in Table 7 .

\begin{tabular}{|l|l|}
\hline Level of belief & Words considered \\
\hline Extreme & $\begin{array}{l}\text { extremist, extremists, fanatical, fanatic, fanatics, firebrand, } \\
\text { firebrands, fundamentalist, fundamentalists, hardline, hardliner, } \\
\text { hardliners, militant, militants, radical, radicals, separatist, separatists }\end{array}$ \\
\hline Strong & devout, faithful, orthodox, pious \\
\hline Moderate & liberal, liberals, moderate, moderates, progressive, progressives, secular \\
\hline
\end{tabular}

Table 7. Levels of belief.

As the table includes words based on labels for people, it does not consider words for related abstract concepts like extremism, radicalism, militancy and separatism. Nor does it consider words related to processes like radicalisation. In fact, as shown earlier, the words extremism and radicalisation were found to be significantly more common in the 2010-2014 articles, compared against the 1998-2009 articles. The term extremism occurs after Islamic $15 \%$ of the time, while extremist $(s)$ occurs after Islamic in a further $31 \%$ of cases.

So before looking in more detail at other terms, it is worth bearing in mind that in articles about Islam the newspapers are more likely to write about the concept of extremism than they used to. Hence even if they have reduced the number of times they talk about Islam or Muslims as extremist, there is evidence that there has been a shift in language towards a greater emphasis on the abstract idea of extremism. This may make the articles superficially less personalised, although it does not remove the general focus on extremism. As found with the 1998-2009 data set, extremism is more likely to be associated with the word Islamic, than Islam or Muslim(s). Proportionally, The Star uses the most extremist words next to Islamic in $22 \%$ of cases (almost 1 in 4). Compare this to The Guardian which does this $6 \%$ of the time (about 1 in 17 cases). The Express is the newspaper most likely to associate Islam with an extremist word ( 1 in 10 cases), while The Mirror does this least (1 in 42 times). For Muslim and its plural it is The Express again which has the highest use of extremist associations ( 1 in 13 cases), and The Guardian which has the least (1 in 83 cases). However, overall in the British press, Muslim(s) occurs next to an extreme word 1 in 31 times, for Islam this is 1 in 21 and for Islamic the proportion is 1 in 8.

The picture for the words Muslim and Muslims combined shows that fewer uses of the word Muslims are linked to extremism overall, with the proportion in 1998-2009 being 1 in 19, while it is 1 in 31 for 2010-2014. The People shows the largest fall in this practice, although we should bear in mind that this is based on a much smaller amount of data than for the other newspapers (e.g. The People mentions Muslims less than 500 times overall in the period 
2010-2014, compared to The Guardian which has over 20,000 mentions in the same period). However, all newspapers show falls in this practice overall.

For the word Islamic, there are also falls in its association with extremism, with the average number of mentions of an extremist word next to Islamic being 1 in 6 in 1998-2009 and 1 in 8 in 2010-2014. The Star and Sun are most likely to link the two words, while it is the least common in The Guardian and its sister newspaper The Observer. The picture for the word Islam is somewhat different, however. Here the average number of mentions of an extreme word near Islam has actually increased slightly, from 1 in 25 to 1 in 21 . The practice has become noticeably more common in The Express, although most newspapers have followed suit. Only The Mirror and The Telegraph show a move away from this practice.

What of the moderate words? It is The Express, Mail and People which are more likely to refer to Muslims as being moderate, with this practice being least common in The Mirror. On average it is Muslims who are more likely to be called moderate ( 1 in 161 cases), as opposed to the concept of Islam ( 1 in 271 cases). However, these figures are much smaller than those for the extremist words. For the 2858 mentions of extreme Muslim(s) in the press, there are only 558 moderate Muslim(s), or rather 5 extremists for every moderate. However, in the 1998-2009 articles, there were 9 mentions of extremist Muslims for every moderate, so we can see evidence that moderate Muslims are starting to get better representation proportionally, although they are still outnumbered. As figure 4 suggests, this is not because moderate Muslims are being referred to more, it is more due to a dip in mentions of extremist ones. For Muslim and its plural, it is The People, Express and Mail which have shown greater increases in mentions of moderate Muslims. however, on average, the number of mentions of moderate Muslims has gone up but only slightly (now 1 in 161 cases).

For cases of Islamic occurring next to a moderate word, this was never common, and has actually fallen slightly. Figures are based on low frequencies, however, and as we have seen earlier, the word Islamic shows a very strong preference for extremist associations. For Islam, there is a slight increase in the proportion of times it occurs next to a moderate word, although again, this is very low overall.

Finally, let us consider the words devout, faithful, orthodox and pious, and how often they occur next to Muslim(s), Islam and Islamic. These words are more likely to occur next to Muslim(s) (about 1 in 140 times) with only a handful of cases of them occurring next to Islamic and Islam.

These strong belief words were barely present in the 1998-2009 articles next to Islam and Islamic too, so we will only consider change over time for the word Muslim(s). What we see are falls for all newspapers, with an average of 1 in 92 references to devout Muslims and similar terms in 1998-2009, dropping to 1 in 140 such references in 2010-2014. 


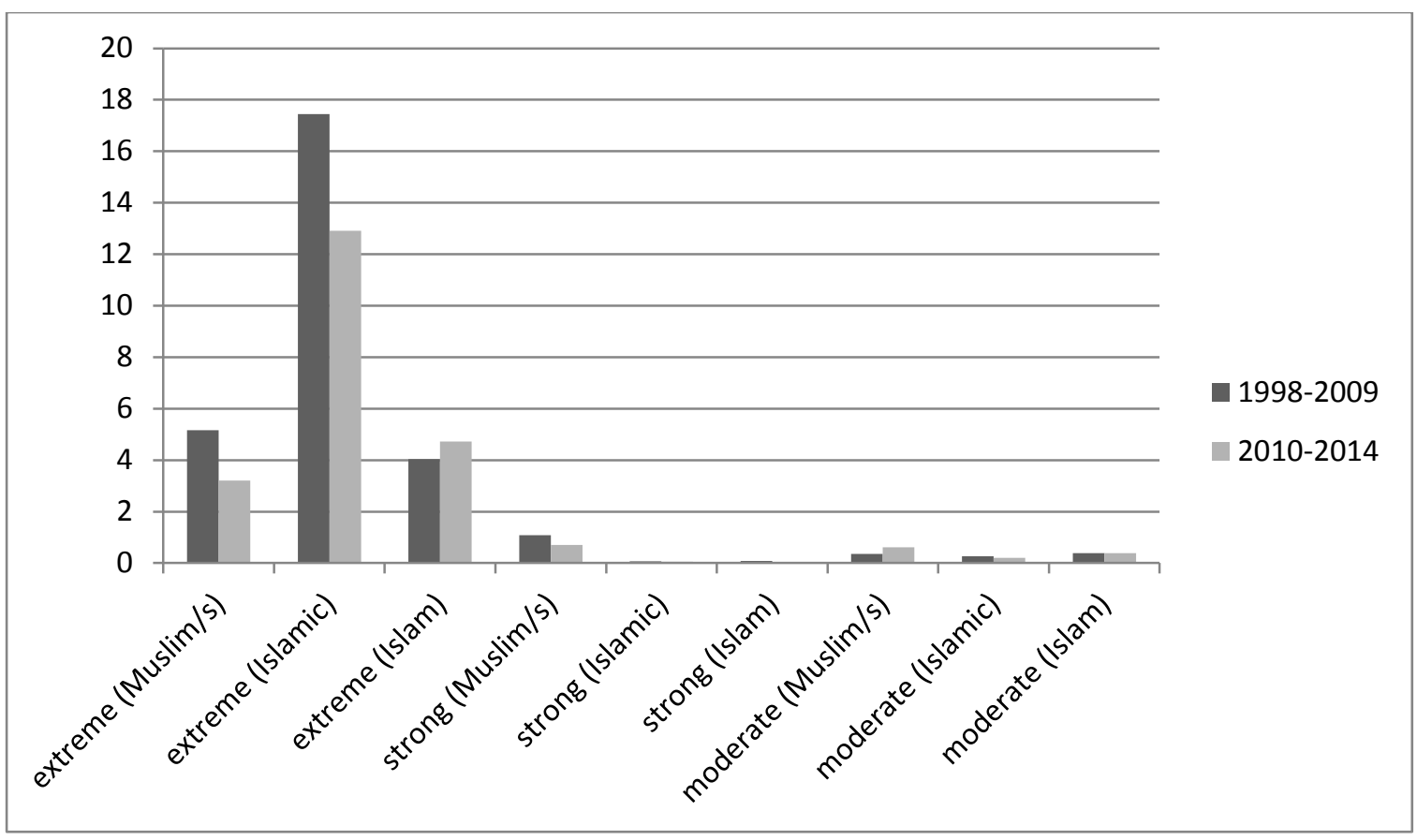

Figure 4. Summary of all data, comparing proportions of change over time.

Figure 4 gives a better sense of the overall picture. We can see, for example, how extremist words are most likely to occur near Islamic, but also how there has been a drop in this association over time, as well as a similar drop in the way that extremist words occur next to Muslim(s). We can also see (small) increases in associations of extremist words with Islam, and moderate words with Muslim(s).

So while references to Muslims as extremists have fallen in the British press since 2010, journalists are writing about the abstract concept of extremism much more frequently than they used to. Also, the concept of Islam is more likely to be referred to as extreme than it used to be. Extremism is still a hot news topic but in this context there has been a move towards focussing more on the religion rather than on its adherents. The ratio of mentions of extreme Muslims to moderate Muslims in the British press is becoming slightly more equal (from 9 to 1 in 1998-2009 to 5 to 1 in 2010-2014). References to devout Muslims have fallen since 2009, although these are still highest in The Mirror. Relatively, The Star and Express have the most references to Islamic extremists, while The Guardian has the fewest. However, the Express refers to moderate Muslims the most too. The Mirror and People have dramatically reduced their references to Islamic extremists. Given the salience of extreme words in Figure 16, let us now explore those words in some more detail.

\subsection{Extremism keywords}

There has been a strong decline in the words fundamentalism, fundamentalist and fundamentalists. Such words were found to have been particularly strong in the years 2001 and 2004, and they have not returned. However, the abstract concept of extremism (as opposed to a people-labelling word like extremist) is more frequent in Corpus B than in Corpus A, as well as three related words, radicalised, radicalisation and grooming. This indicates a major shift in language around extremism, which is more concerned with the process of becoming extreme, rather than labelling people as such.

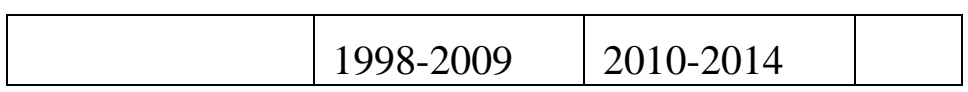




\begin{tabular}{|l|l|l|l|}
\hline fundamentalism & 22.4 & 10.3 & $\downarrow$ \\
\hline fundamentalist & 38.1 & 18.8 & $\downarrow$ \\
\hline fundamentalists & 27.1 & 13.0 & $\downarrow$ \\
\hline extremism & 42.8 & 69.6 & $\uparrow$ \\
\hline radicalised & 8.3 & 22.3 & $\uparrow$ \\
\hline radicalisation & 6.1 & 19.9 & $\uparrow$ \\
\hline grooming & 2.7 & 11.2 & $\uparrow$ \\
\hline
\end{tabular}

Table 8. Extremism keywords.

\subsection{Reasons for radicalisation}

Radicalisation has been mentioned in several sections of this chapter so far, so a closer look at radicalisation and the claimed causes of radicalisation seems appropriate - especially as it points to a major difference between Corpus A and Corpus B and hence a source of dynamism in the discourse over time.

References to radicalisation have increased since 1998-2009, with there being almost double the number of mentions of that word in the shorter 2010-2014 dataset. The main pattern we see over time is increasing attribution of blame for radicalisation on extremist Islam - in 1998-2009 this occurred in 1 in 3 cases. By 2014 it is 2 in 3 cases. Yet the attribution of blame to government policy has decreased over time, from 1 in 3 cases in 1998-2009 to 1 in 12 in 2014. The invasions of Iraq and Afghanistan, while still mentioned, are now seen as almost historical factors attributable to the 'Labour years', rather than as being relevant to the present situation.

Two of the less frequent explanations for radicalisation found in the 1998-2009 data, "grievance culture" and "multi-culturism", seem to have largely disappeared from the discourse around radicalisation in 2010-2014.

In the pie charts that follow, the different causes of radicalisation presented by the press are shown. The first pie chart shows the relative frequency of causes in the period 1998-2009, the second covers 2010-2014, while the third shows 2014 on its own. Below is a brief key explaining each cause listed in the tables.

- Extremist Islam - cases where extremists are described as targeting non-extremists. This is often described as occurring in prisons, schools or universities.

- Government Policy - this usually refers to foreign policy e.g. the invasion of Iraq, but in a rarer set of cases can also refer to a view that the government has failed to properly tackle extremism at home, or that policies that remove civil liberties are to blame.

- Alienation of Muslims - this refers to Islamophobia, the view that Muslims and Muslim communities are cut-off from others in the UK, and that youth in particular are disaffected.

- Wars - references to conflict abroad, particularly the Israel-Palestine conflict, causing anger in the UK but also, more recently, the conflict in Syria engaging British Muslims 
- Multiculturalism - blame on a general culture of accepting, even promoting difference in the UK

- Poverty - economic reasons, especially cases of Muslims living in areas of economic deprivation

- Grievance Culture - the view that Muslims wrongly feel victimised. This is similar to "alienation of Muslims", but here the sense of victimisation is described as misguided.

- Others - "one-off" reasons such as individual Muslims experiencing torture, or more global trends such as liberalising modernisation or capitalism

These three pie charts alone are sufficient cause to cast doubt on the use of any time bound analysis to cast light on what happens either before or after the period studied. The results from Corpus A are very different in terms of the proportions with which causes of radicalization are mentioned. Figure 7 shows that one year in Corpus B is a much closer match to the results of Corpus B than the comparison to Corpus A produces, i.e. there is some evidence for internal consistency within Corpus B, yet evidence of real change between Corpus A and Corpus B.

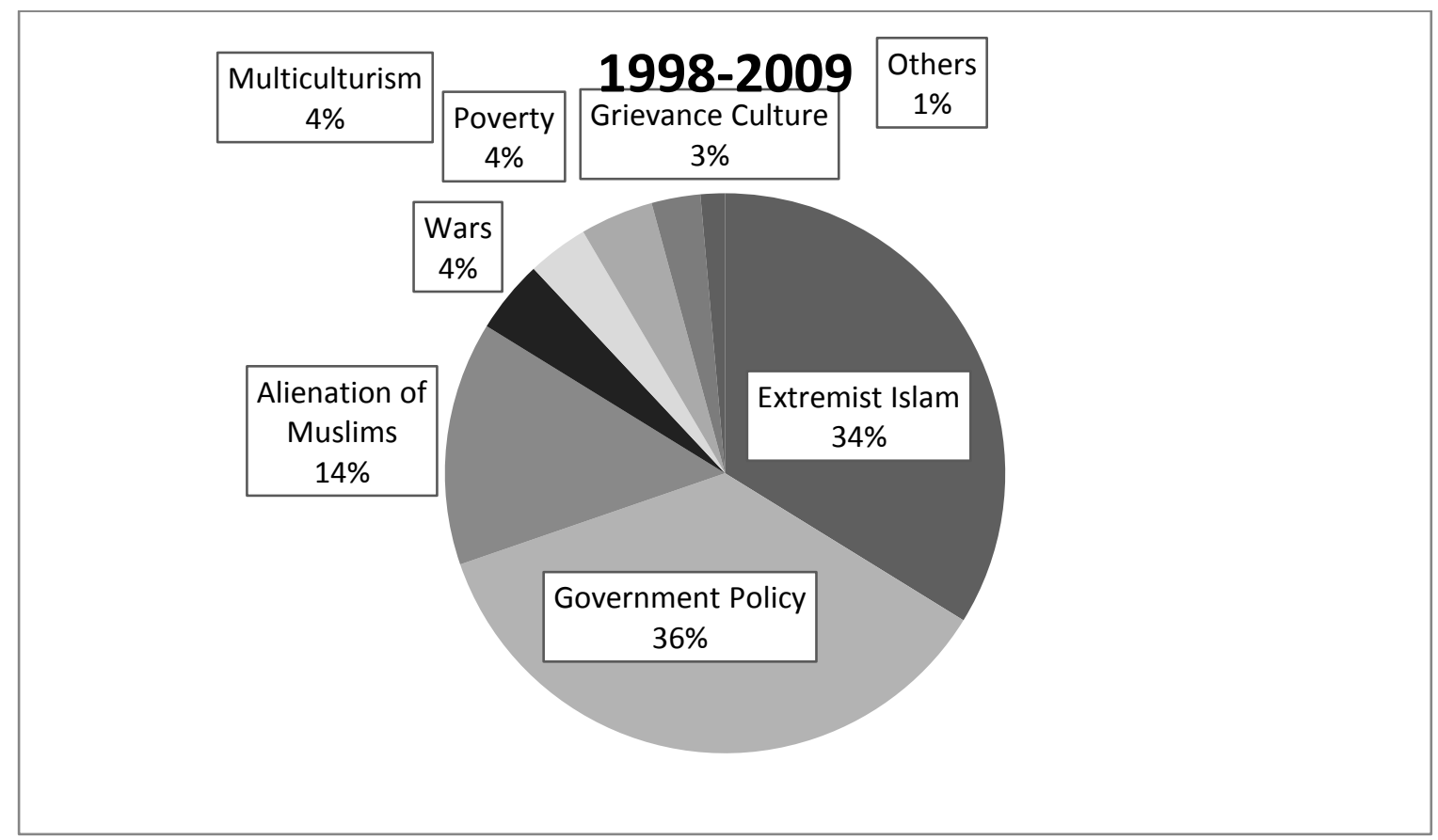

Figure 5: Claimed causes of radicalisation in the press in 1998-2009. 


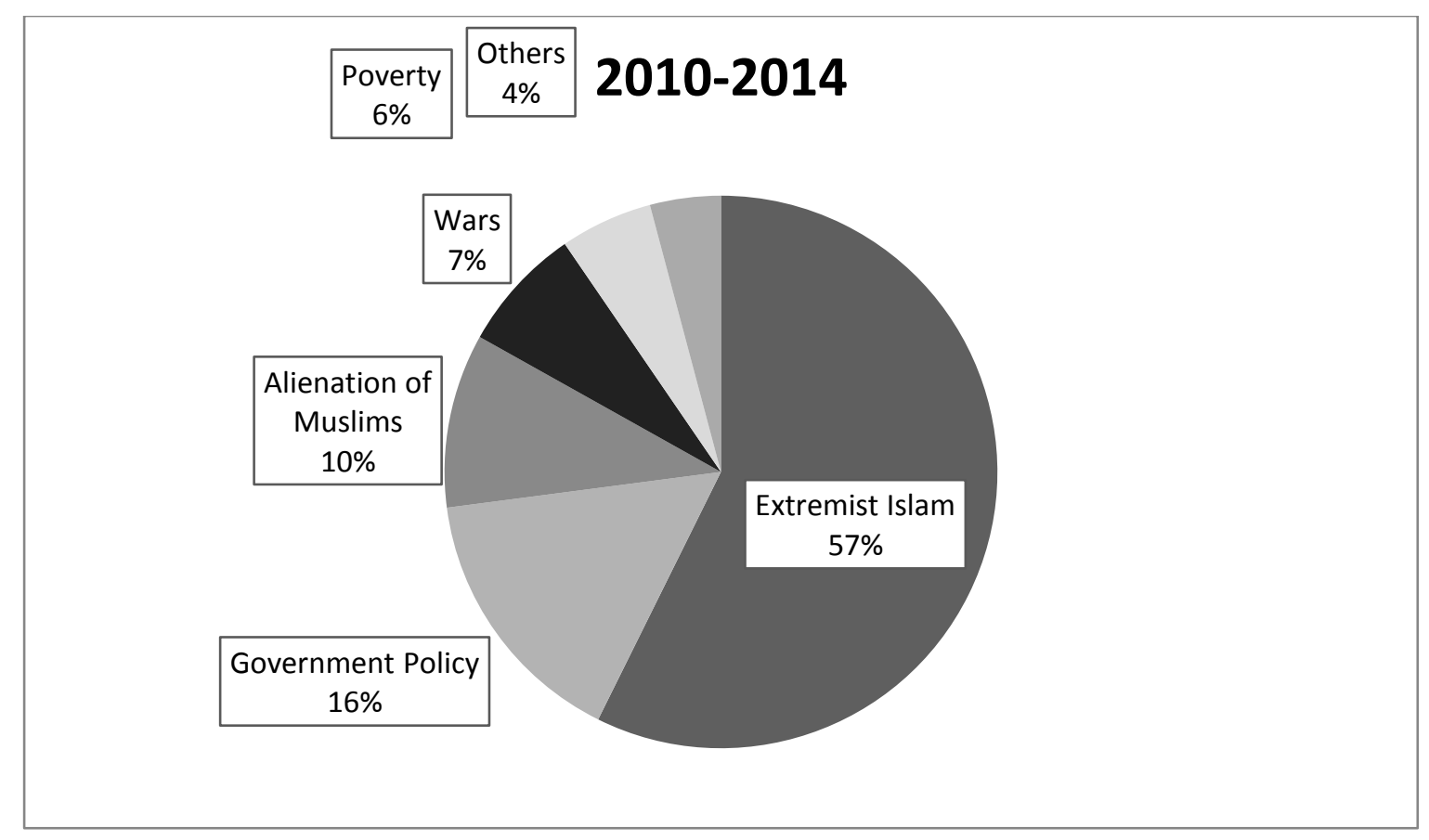

Figure 6: Claimed causes of radicalisation in the press in 2010-2014.

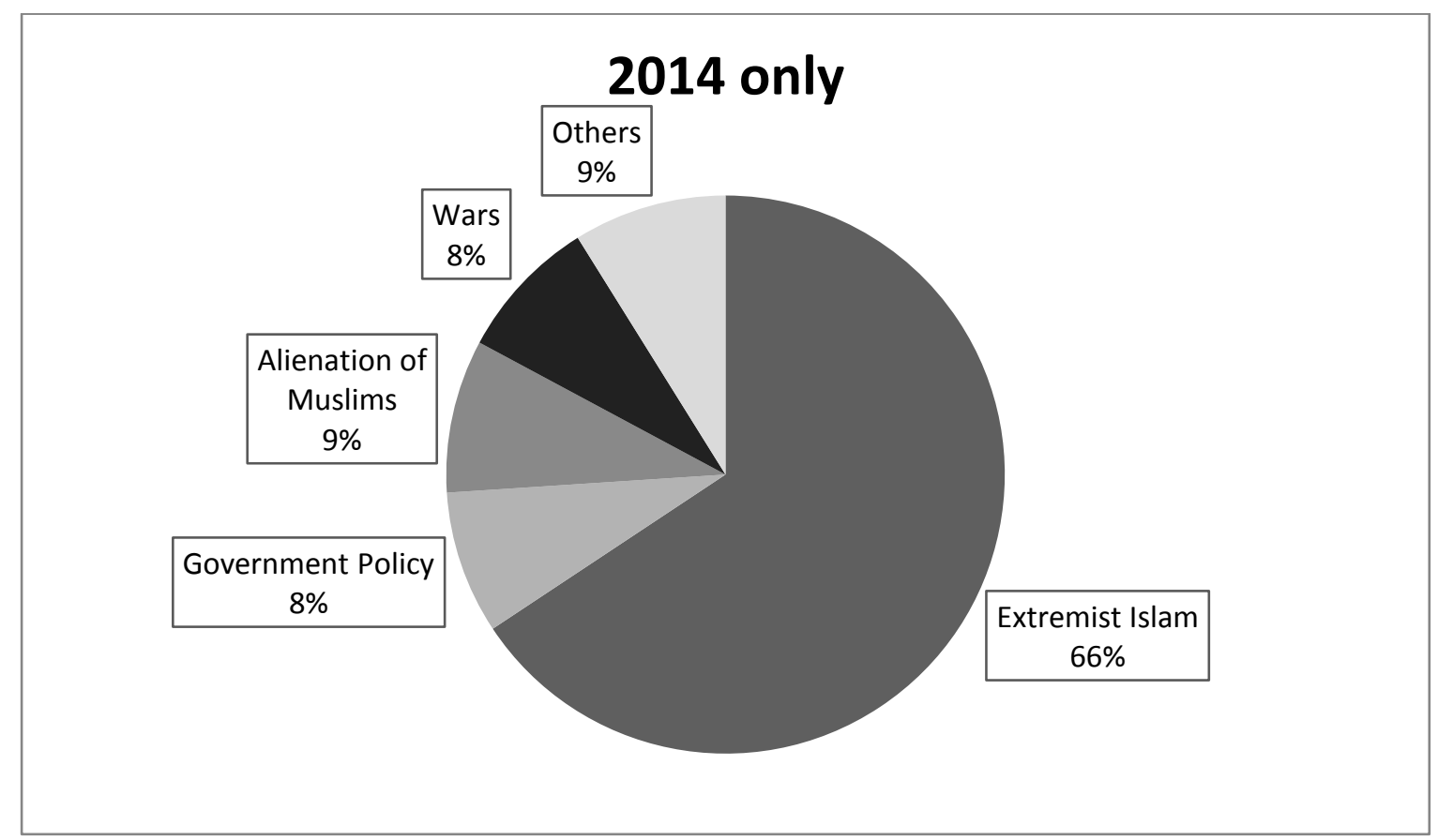

Figure 7: Claimed causes of radicalisation in the press in 2014.

\section{Conclusion}

There is little doubt that the availability of corpus data which has allowed large scale investigations of discourses in certain genres, especially the press, has been one of the most notable methodological developments in discourse analysis in the past couple of decades. Such analyses, however, are of necessity time bound - the analysts collect data between two dates. No matter how exhaustive the collection of that data, the capacity of the data and its associated analysis to cast light on the discourse that preceded or followed that data is, of necessity, limited. In this chapter we have argued for a new methodological approach - the 
repeat of major studies of this sort and a comparison across time of relevant results to begin to approach the question of how discourse may shift through large scale systematic studies.

To demonstrate the need for this, we repeated the study of Baker et al (2013), collecting data for the six years following their analysis. By doing that we were able to show the need for such a study - discourse may indeed shift over time. Some elements remain the same, some shift by a small degree, some shift quite substantially. Each shift has the capacity to expose a driver in discourse in society - for example, how the causes of radicalization have been shifted in the UK press also has the effect of backgrounding blame for some and foregrounding blame for others. To simply assume that on the basis of the examination of 13 years of newspaper discourse (Corpus A) that we can generalize beyond those 13 years is naïve - yet we do see statements in the literature that seem, at least implicitly, to suggest that this is possible.

The methodological innovation that is needed to counteract this situation is simple discourse must be monitored. Studies should be restaged, and the findings of time bound analyses should not be assumed to be generalizable beyond the period studied unless there is clear evidence from a follow on study that such a generalization is warranted. However, on the basis of the study undertaken, we would predict that static findings between an original study and a follow on study, especially in a dynamic medium such as press reportage, are likely to be the exception rather than the norm.

\section{References}

Baker, P., Gabrielatos, C., Khosravnik, M., Kryzanowski, M., McEnery, T. and Wodak, R. (2008) 'A useful methodological synergy? Combining critical discourse analysis and corpus linguistics to examine discourses of refugees and asylum seekers in the UK press', Discourse and Society, Volume 19, Issue 3, pp 273-306.

Baker, P., Gabrielatos, C. and McEnery, T. (2013) Discourse Analysis and Media Attitudes: The representation of Islam in the British press. Cambridge University Press, Cambridge.

Blinder, S. and Allen, W. (2016) 'Constructing immigrants: portrayals of migrant groups in British national newspapers, 2010-2012’, International Migration Review, Voume 50, Issue 1, pp 3-40.

Evans, M. and Schuller, S. (2015) 'Representing "terrorism": The radicalization of the May 2013 Woolwich attack in British press reportage', Journal of Language, Aggression and Conflict, Volume 3, No. 1, pp 128-150.

Kambites, C.J. (2014) "'Sustainable Development": the "Unsustainable" Development of a Concept in Political Discourse', Sustainable Development, Volume 22, pp 336-348.

L'Hôte, E. (2010) 'New Labour and globalization: Globalist discourse with a twist?', Discourse and Society, Volume 21, No. 4, pp 355-376. 